\title{
Diving behaviour of the critically endangered tope shark Galeorhinus galeus in the Natural Reserve of Bahia San Blas, northern Patagonia
}

\author{
Juan Martín Cuevas ${ }^{1,2,3^{*}}$, Mirta García ${ }^{2,4}$ and Edgardo Di Giacomo 3,5
}

\begin{abstract}
Background: Tope sharks (Galeorhinus galeus) aggregate in large numbers during spring and summer in closed gulfs and bays in northern Patagonia; these locations are considered the main nursery areas for the species. However, little is known about the spatial ecology or diel behaviour of this critically endangered species. The aim was to evaluate the short-term diving behaviour and habitat preferences of tope sharks using electronic tagging.

Findings: Five female tope sharks, four adult and one sub-adult, were tagged with pop-up satellite archival tags in the Natural Reserve of Bahía San Blas, northern Patagonia, during spring 2011 and 2012. High-resolution archived data were collected for 40 days, including 29 days for two recovered tags. Sharks travelled up to $51.2 \mathrm{~km}$ after release. Archived data indicated that female tope sharks preferred to remain within $24.5 \mathrm{~m}$ of the surface and that there were no diel changes in preference. Individuals spent most of the time within $10 \mathrm{~m}$ of the surface during the day (80\%) and at night (83\%), and were primarily in water between $17^{\circ} \mathrm{C}$ and $19^{\circ} \mathrm{C}$ (day, $75 \%$; night, $70 \%$ ). Moreover, tope sharks exhibited vertical oscillatory movement ('yo-yo diving'). Maximum vertical speeds and dive depths were recorded at night. Ascents from depth had a greater speed than descents, overall.
\end{abstract}

Conclusions: Female tope sharks were found in shallow coastal areas during November at Bahía San Blas, near the surface at relatively restricted depths and temperatures. Longer tracking periods will be important for describing the species' migratory movements across the south-west Atlantic.

Keywords: Argentina, Marine protected areas, Pop-up satellite archival transmitter, 'yo-yo diving'

\section{Introduction}

The use of shark satellite tagging has increased over the past decade, facilitating the description of migratory patterns, habitat use and diving behaviour for a variety of species $[1,2]$. Behavioural data provided by these telemetry studies provide valuable information for the management of this vulnerable group of fishes [1].

The tope shark, Galeorhinus galeus, is a transient coastal species [3] distributed between Brazil and Argentina in the south-west Atlantic Ocean [4]. It has been hypothesized that tope sharks comprise a single population across Argentina, Uruguay and Brazil, migrating between

\footnotetext{
* Correspondence: cuevasjuanmartin@gmail.com

${ }^{1}$ Instituto de Medio Ambiente, Universidad Nacional de la Matanza, Florencio Varela 1903, Buenos Aires, Argentina

${ }^{2}$ Facultad de Ciencias Naturales y Museo, Universidad Nacional de La Plata, Av. Del Bosque s/n, La Plata, Argentina

Full list of author information is available at the end of the article
}

southern Brazil and northern Patagonia during spring $[5,6]$. As a result of the large shark aggregations in closed gulfs and bays of northern Patagonia during spring and summer, these areas are believed to be the primary nursery grounds for the species [5-7].

In the south-west Atlantic Ocean, tope sharks are classified as critically endangered [8], largely as a result of overfishing. This study provides the first observations of short-term diving behaviour and habitat preferences of G. galeus in northern Patagonia and the south-west Atlantic Ocean.

\section{Methods \\ Study site}

Bahia Anegada and Bahia Unión are shallow (less than $2 \mathrm{~m}$ during high tides) areas inside the Natural Reserve of Bahía San Blas (NRBSB), with sandbanks, small inner rivers, natural channels and small islands in the northern 


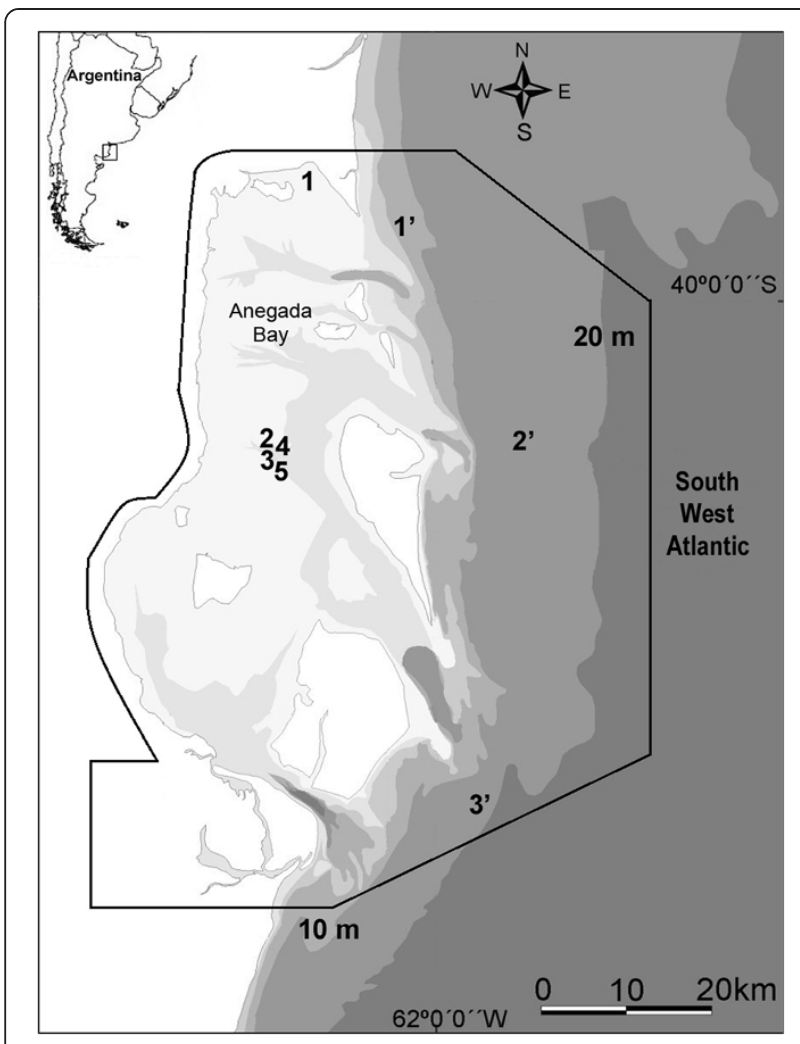

Figure 1 Tagging site ( 1 to 5 ) and pop- off location ( 1 ' to $3^{\prime}$ ). Solid line: limits of the NRBSB.

zone (Figure 1). The northern edge of the NRBSB is highly influenced by discharges of nutrient-rich waters from the Colorado River and the southern edge receives nutrients from the Negro River [9]. The resulting abundance of food coupled with a scarcity of large predators make these bays important spawning and nursery areas for bony [10] and cartilaginous fishes [5,11].

\section{Tagging task}

Five individuals were tagged inside the NRBSB in November 2011 and 2012 (Figure 1). The sharks were captured with sport fishing gear using barbless hooks baited with mackerel (Scomber scombrus) or Brazilian menhaden (Brevoortia aurea). The length (total length) and sex of each individual was recorded before external application of an MK10 pop-up satellite archival transmitter (PSAT) tag [12]. The first three individuals were tagged on the right side of the base of the dorsal fin with a stainless steel harpoon with the tag secured intramuscularly by a polymer dart. The next two individuals were tagged using a plastic sheep ear ID tag to anchor the PSAT on the front side of the dorsal fin. The PSAT tags were programmed for a deployment period of either 180 days (Sharks 1 to 3 ) or 270 days (Sharks 4 and 5). Tags were programmed to record water temperature, depth and light level at 5-s intervals. These data were automatically binned into 6-hour histograms (depth bins: the first bin for depths shallower than $10 \mathrm{~m}$, then bins at $10-\mathrm{m}$ increments, 10 to $20 \mathrm{~m}$ and so on, and the last bin for depths greater than $200 \mathrm{~m}$; temperature bins: the first bin for temperatures below $3^{\circ} \mathrm{C}$, then bins at $2^{\circ}$ increments, $3^{\circ} \mathrm{C}$ to $5^{\circ} \mathrm{C}$ and so on, then the last bin for temperatures above $27^{\circ} \mathrm{C}$ ). The automatic release feature was to be triggered if tags recorded depth variations of $\pm 3 \mathrm{~m}$ for 48 hours at a constant depth.

\section{Data analysis}

Igor Pro Version 6.2 (WaveMetrics) and the Data Analysis Program 3.0 (Wildlife Computers) were used to analyze the tracking data. Depth and temperature preference distribution histograms during day and night periods were constructed. The vertical speed of ascents and descents as well as maximum dive depths were calculated from depth profiles (Sharks 1 and 2) during the day, at night, and at sunset and sunrise. Local hour intervals were defined as: 9 to 10,12 to 13,15 to 16 (day) and 21 to 22,0 to 1,3 to 4 (night). The sunset and sunrise period at the study area were obtained from dawn and dusk data for the tracking period using the Navy Hydrographic Service. Vertical speed and dive depths were defined, assuming constant speed for straight ascent and descent movements $\left(0^{\circ}\right.$ and $\left.45^{\circ}\right)$ between two consecutive points.

Table 1 Tagging information for Galeorhinus galeus

\begin{tabular}{|c|c|c|c|c|c|c|c|}
\hline $\begin{array}{l}\text { Shark } \\
\text { number }\end{array}$ & $\begin{array}{l}\text { Tagging } \\
\text { depth }(\mathrm{m})\end{array}$ & $\begin{array}{l}\text { Tagging } \\
\text { date }\end{array}$ & Tagging location & Pop-off date & Pop-off location & $\begin{array}{l}\text { Distance } \\
\text { moved }(\mathrm{km})\end{array}$ & Note \\
\hline 1 & 5 & $11 / 11 / 2011$ & $40^{\circ} 7^{\prime} 37.78^{\prime \prime} \mathrm{S} 62^{\circ} 16^{\prime} 37.05^{\prime \prime} \mathrm{W}$ & $19 / 11 / 2011$ & $39^{\circ} 59^{\prime} 34.80^{\prime \prime} \mathrm{S} 62^{\circ} 1^{\prime} 51.60^{\prime \prime} \mathrm{W}$ & 19.4 & $\begin{array}{l}\text { Tag } \\
\text { recovered }\end{array}$ \\
\hline 2 & 2.5 & $13 / 11 / 2011$ & $39^{\circ} 56^{\prime} 49.61^{\prime \prime} \mathrm{S} 62^{\circ} 14^{\prime} 31.85^{\prime \prime} \mathrm{W}$ & $04 / 12 / 2011$ & $40^{\circ} 11^{\prime} 9.60^{\prime \prime} \mathrm{S} 61^{\circ} 54^{\prime} 46.80^{\prime \prime} \mathrm{W}$ & $29.91^{*} 48.68^{\#}$ & $\begin{array}{l}\text { Tag } \\
\text { recovered }\end{array}$ \\
\hline 3 & 2.5 & 13/11/2011 & $40^{\circ} 7^{\prime} 28.16^{\prime \prime} \mathrm{S} 62^{\circ} 16^{\prime} 8.56^{\prime \prime} \mathrm{W}$ & $24 / 11 / 2011$ & $40^{\circ} 33^{\prime} 54.00^{\prime \prime} \mathrm{S} 61^{\circ} 56^{\prime} 27.60^{\prime \prime} \mathrm{W}$ & 51.12 & $\begin{array}{l}\text { Tag not } \\
\text { recovered }\end{array}$ \\
\hline 4 & 2 & 18/11/2011 & $40^{\circ} 7^{\prime} 42.97^{\prime \prime} \mathrm{S} 62^{\circ} 16^{\prime} 11.88^{\prime \prime} \mathrm{W}$ & Expected date 18/6/13 & - & - & Tag failed \\
\hline 5 & 2 & 18/11/2011 & $40^{\circ} 7^{\prime} 38.59^{\prime \prime} \mathrm{S} 62^{\circ} 1549.08^{\prime \prime} \mathrm{W}$ & Expected date 18/6/13 & - & - & Tag failed \\
\hline
\end{tabular}

*, minimum distance travelled; ${ }^{*}$, maximum distance travelled. 


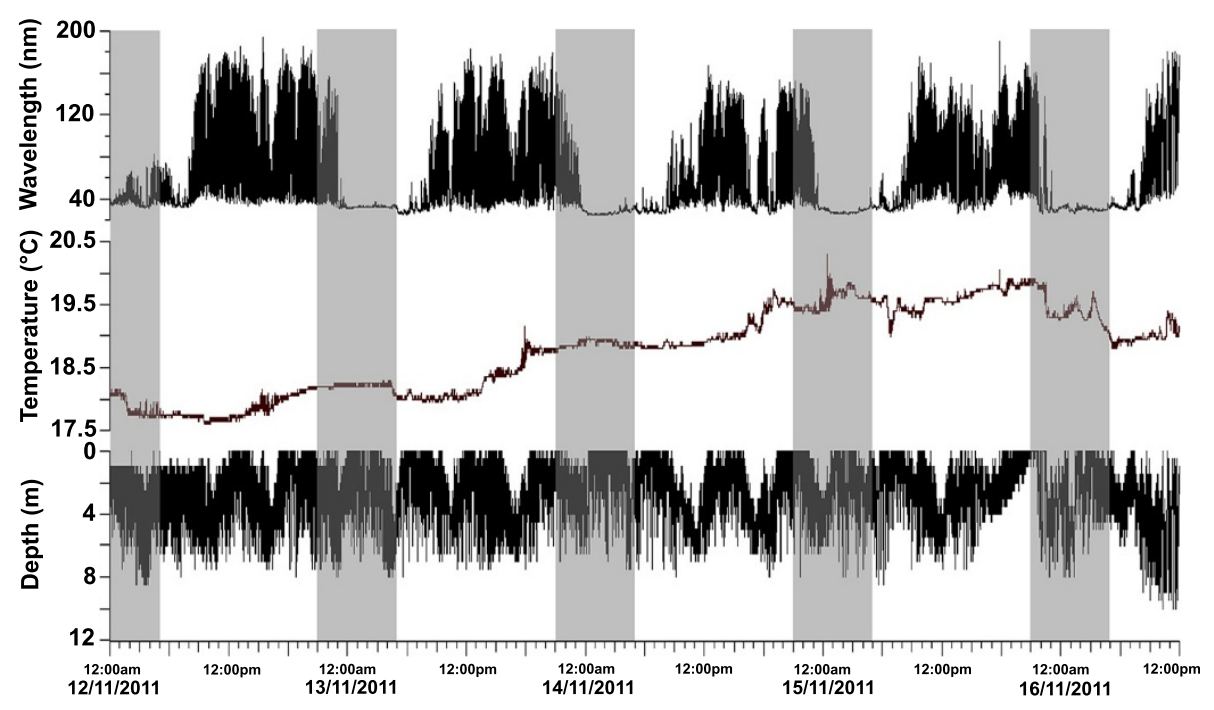

Figure 2 Full archival record of Shark 1 during the tracking period. Shaded bars indicate night time.

\section{Ethical approval}

As Galeorhinus galeus is fished and commercialized in Argentina, it is regulated by fishery acts. This work was carried out according to the code of good practice for sustainable recreational fisheries suggested by the management plan (not implemented yet) of the Natural Reserve of Bahía San Blas, in compliance with act $\mathrm{N}^{\circ}$ 217/07 for sustainable angling fishing in the Province of Buenos Aires for coastal sharks.

\section{Results}

Five female G. galeus (122 to $140 \mathrm{~cm}$ total length) were tagged in the NRBSB, northern Patagonia (Table 1). The first two tags were recovered and full archival datasets were downloaded (696 hours). Tag 3 transmitted 1,917 messages but the remaining two tags failed. Movement behaviour was tracked for a total of 40 days. All sharks remained within the limits of the NRBSB until the tags popped off (Figure 1). Complete tagging and pop-off details are reported in Table 1 . The tracked sharks had a limited vertical distribution near the surface layer and also swam in waters within a narrow temperature range (Figures 2 and 3). All sharks swam $80 \%$ of the day and $83 \%$ of the night at depths shallower than $10 \mathrm{~m}$. The remainder of the time was spent between $10 \mathrm{~m}$ and $20 \mathrm{~m}$ (day, 20\%; night, 16.5\%) or between $20 \mathrm{~m}$ and $30 \mathrm{~m}$ (day and night $<1 \%$ ). The tracked sharks swam predominantly in water that was between $17^{\circ} \mathrm{C}$ and $19^{\circ} \mathrm{C}$ (day, $75 \%$;

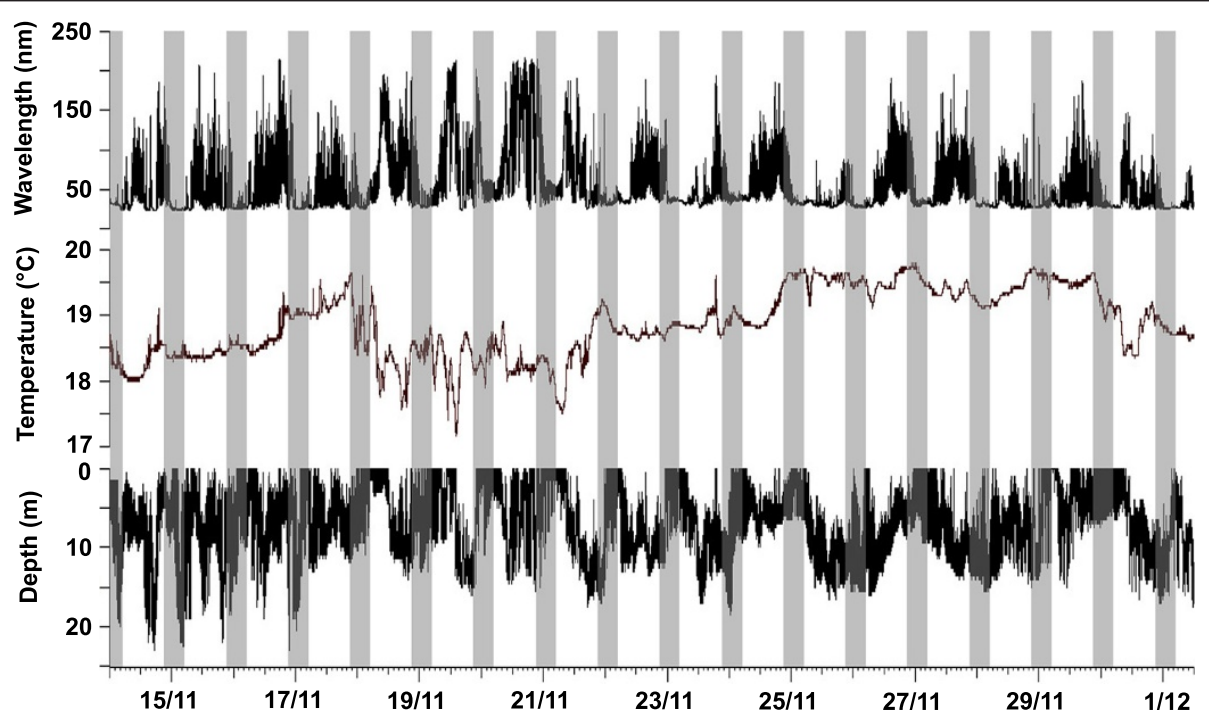

Figure 3 Full archival record of Shark 2 during the tracking period. Shaded bars indicate night time. 


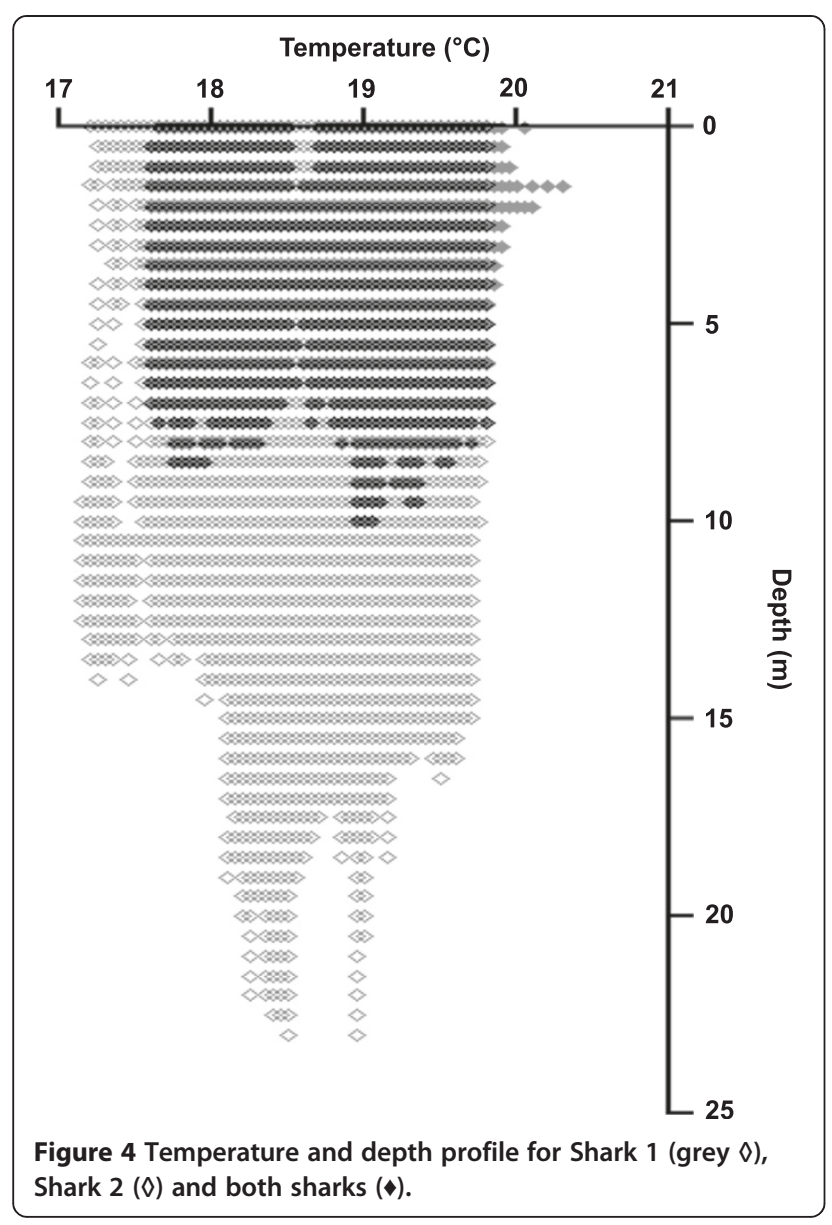

Figure 4 Temperature and depth profile for Shark 1 (grey $\diamond$ ), Shark $2(0)$ and both sharks $(\star)$. night, 70\%). Other temperatures logged were $19^{\circ} \mathrm{C}$ to $21^{\circ} \mathrm{C}$ (day, 24\%; night, $28 \%$ ) and $15^{\circ} \mathrm{C}$ to $17^{\circ} \mathrm{C}$ (day, $0.5 \%$; night, 2\%). Shark 2 (mean, $6.48 \pm 4.40 \mathrm{~m}$ ) exhibited a wider range of depth use than did shark 1 (mean, $2.57 \mathrm{~m}, \pm 1.84$ ), and a wider thermal range (Figure 4). Sharks swam near the surface $(0.5$ to $0.0 \mathrm{~m})$ for the most part, with maximums of 9 (Shark 1) and 41 min (Shark 2) and a vertical oscillatory movement changing depth over a short period of time ( $<1 \mathrm{~min}$ ), termed 'yo-yo diving, was recorded (Sharks 1 and 2). Shark 1 swam exclusively in depths $<10 \mathrm{~m}$, mostly at 1 to $2 \mathrm{~m}$ during both day and night (Figure 5). Sharks 1 and 2 used areas with similar water temperatures $\left(18.79 \pm 0.67^{\circ} \mathrm{C}\right.$, and $18.89 \pm 0.50^{\circ} \mathrm{C}$, respectively). The maximum vertical speeds and dive depths were recorded at night (Additional file 1: Table S1) and overall ascending movements $(3.36 \pm 0.17 \mathrm{~m}$ and $3.40 \pm 0.08 \mathrm{~m}$ for Sharks 1 and 2, respectively) were larger than descending movements $(2.34 \pm 0.24 \mathrm{~m}$ and $2.50 \pm 0.26 \mathrm{~m}$, for Sharks 1 and 2, respectively, Additional file 2: Figure S1 and Additional file 3: Figure S2).

\section{Discussion}

The deployment time for PSATs attached to Sharks 1, 2 and 3 was less than the programmed deployment period because the tag pin burnt out prematurely when the sharks had remained at $6 \pm 3 \mathrm{~m}$ deep for 48 hours. As the sharks mostly frequented shallow and turbid coastal waters, it was not possible to estimate geolocation based on light-level data.

\section{Vertical movements}

During the tracking period, tagged G. galeus exhibited regular oscillatory movements in which they rapidly changed depth $(<1 \mathrm{~min}$.). Explanations for this so called 'yo-yo'

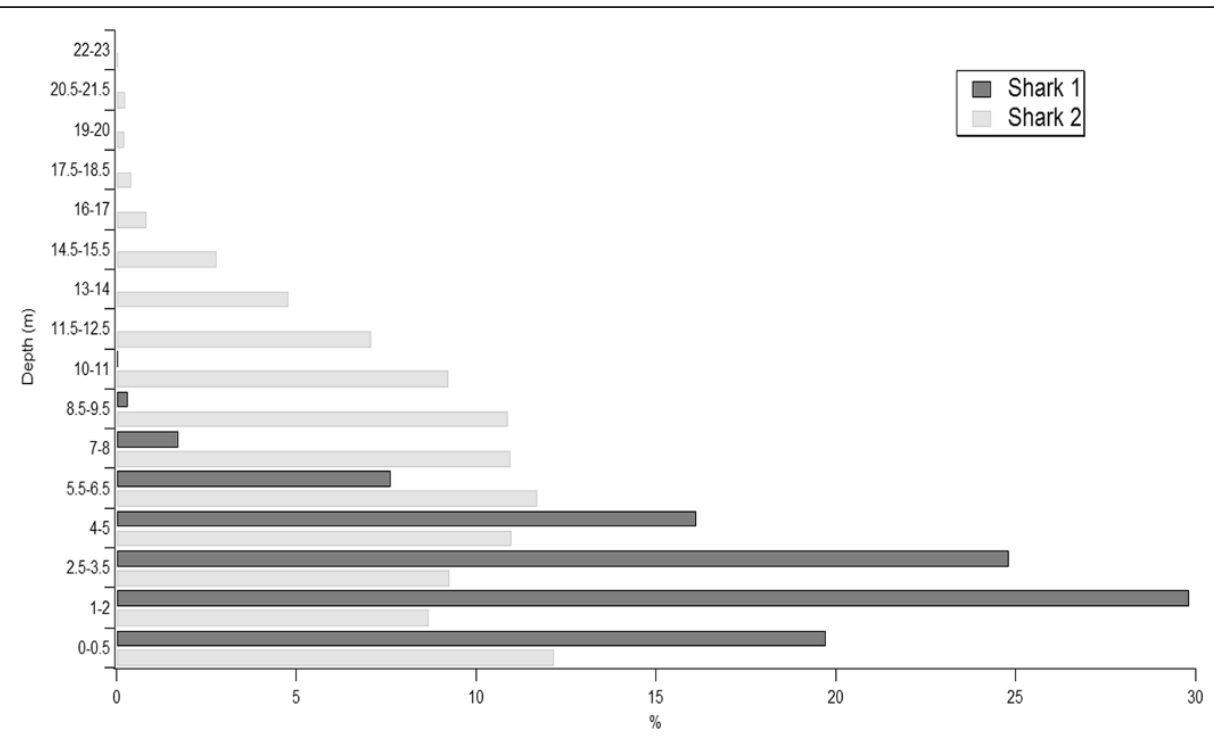

Figure 5 Detailed histogram of percentage time-at-depth for Shark 1 and Shark 2. 
diving [13] could include searching for cues [14] or for prey, such as striped weakfish (Cynoscion guatucupa), which are abundant in the NRBSB during November [11]. Although, tracked G. galeus swam in shallow depths in the NRBSB, they showed higher ascending and descending speeds than similar-sized females in Australia [15].

\section{Depth distribution}

In Golfo Nuevo, Patagonia, Elías et al. [7] caught male $(40 \mathrm{~m})$ and female tope sharks $(>110 \mathrm{~m})$ at greater depths than those in which tope sharks frequented in the NRBSB. However, G. galeus is fished at similar depths to those used in our study (6 to $15 \mathrm{~m}$ and 20 to $30 \mathrm{~m}$ ) in Uruguay [6]. In southern Brazil, G. galeus are abundant at depths between 40 and $350 \mathrm{~m}$ and have been recorded at depths up to $375 \mathrm{~m}$ [16]. In southern Australia, West and Stevens [15] found that G. galeus spent $91 \%$ of their time on the continental shelf $(<200 \mathrm{~m})$, with a peak at 50 to $75 \mathrm{~m}$ for females and 75 to $100 \mathrm{~m}$ for males. The relatively shallow depths that tope sharks utilized during this study might be an artefact of the short period of time tracked, as sharks remained close to the coast and inside the NRBSB for most of the tracking period. Surface swimming behaviour for prolonged periods (hours to days or weeks) has been observed in G. galeus in southern Australia [15]; however, we only recorded surface swimming for periods shorter than 1 hour.

\section{Temperature preferences}

In Golfo Nuevo, females were caught in deeper (>110 m) and cooler $\left(11^{\circ} \mathrm{C}\right.$ to $\left.12^{\circ} \mathrm{C}\right)$ waters than those used by female tope sharks in the NRBSB [7]. Female tope sharks experience similar temperatures in southern Brazilian waters from April to June $\left(18^{\circ} \mathrm{C}\right.$ to $\left.20^{\circ} \mathrm{C}\right)$ [17]. In Uruguay, De Buen [18] found lower temperature preferences $\left(15.9^{\circ} \mathrm{C}\right.$ to $14^{\circ} \mathrm{C}$ ) than our study. West and Stevens [15] showed that tope sharks from southern Australia spent $63 \%$ of their time in cooler waters $\left(13^{\circ} \mathrm{C}\right.$ to $\left.16^{\circ} \mathrm{C}\right)$, and $30 \%$ in a similar temperature range $\left(16^{\circ} \mathrm{C}\right.$ to $\left.20^{\circ} \mathrm{C}\right)$ to tope sharks in the NRBSB.

\section{Conclusions}

Within the NRBSB, female Galeorhinus galeus exhibited oscillating diving behaviour in a narrow depth and temperature range and resided primarily near the surface. Surface swimming behaviour and 'yo-yo diving' were also observed. Longer tracking periods will be necessary to confirm regional migratory movements across the species' entire distribution for the successful development of an effective coordinated Regional Species Conservation Plan for the south-west Atlantic population.

\section{Additional files}

Additional file 1: Table S1. Summary of dive information for Galeorhinus galeus in the NRBSB.

Additional file 2: Figure S1. Ascent and descent vertical speed $\left(\mathrm{m} \mathrm{s}^{-1}\right)$ movements of Galeorhinus galeus in the NRBSB.

Additional file 3: Figure S2. Figure S2 Maximum vertical dive height (m) of Galeorhinus galeus in the NRBSB.

\section{Abbreviations}

NRBSB: Natural Reserve of Bahía San Blas; PSAT: Pop-up satellite archival transmitter.

\section{Competing interests}

The authors declare that they have no competing interests.

\section{Authors' contributions}

JMC made substantial contributions to the design, acquisition, analysis and interpretation of data. MG drafted the manuscript and revised it critically for important intellectual content. EDG participated in the manuscript coordination and helped to draft it. All authors read and approved the final manuscript.

\section{Acknowledgements}

The authors would like to thank Luis and Leo Carbone, Hugo Reisvig, Gustavo Chiaramonte, Phillipe Miller, Matias Braccini, Naomi Pleizier and Robert Lennox.

\section{Funding}

JMC was supported by a scholarship from Universidad National de La Matanza. This work was supported by a Rufford Small Grant (No 9515-1) and The Mohamed Bin Zayed Species Conservation Fund (No 11252181).

\section{Author details}

${ }^{1}$ Instituto de Medio Ambiente, Universidad Nacional de la Matanza, Florencio Varela 1903, Buenos Aires, Argentina. 'Facultad de Ciencias Naturales y Museo, Universidad Nacional de La Plata, Av. Del Bosque s/n, La Plata, Argentina. ${ }^{3}$ Grupo de Estudio de Peces Cartilaginosos CONDROS, Instituto de Biología Marina y Pesquera Alte, Storni, Universidad Nacional de Comahue, Güemes 1030, San Antonio Oeste, Río Negro, Argentina. ${ }^{4}$ CONICET, Consejo Nacional de Investigaciones, Científicas y Técnicas, Av. Rivadavia 1917 (C1033AAJ), Buenos Aires, Argentina. ${ }^{5}$ Universidad Nacional del Comahue, Güemes 1030, San Antonio Oeste, Río Negro, Argentina.

Received: 11 February 2014 Accepted: 3 June 2014

Published: 10 July 2014

\section{References}

1. Hammerschlag N, Gallagher AJ, Lazarre DM: A review of shark satellite tagging studies. J Exp Mar Bio Ecol 2011, 398:1-8.

2. Papastamatiou YP, Lowe CG: An analytical and hypothesis-driven approach to elasmobranch movement studies. J Fish Biol 2012, 80:1342-1360

3. Speed C, Field I, Meekan M, Bradshaw C: Complexities of coastal shark movements and their implications for management. Mar Ecol Prog Ser 2010, 408:275-293.

4. Chiaramonte GE: Biología y pesquería del tiburón vitamínico Galeorhinus galeus (Linnaeus, 1758) (Pisces Elasmobranchii: Triakidae) en Puerto Quequén. Provincia de Buenos Aires, Argentina: Universidad Nacional de Buenos Aires; 2001:70.

5. Lucifora LO, Menni RC, Escalante AH: Reproductive biology of the school shark, Galeorhinus galeus, off Argentina: support for a single south western Atlantic population with synchronized migratory movements. Environ Biol Fishes 2004, 71:199-209.

6. Walker T: Galeorhinus galeus fisheries of the world. In Case Studies of the Management of Elasmobranch Fisheries. Edited by Shotton R. Rome: Food and Agriculture Organization; 1999:728-773. 
7. Elías I, Rodriguez A, Hasan E, Reyna MV, Amoroso R: Biological observations of the tope shark, Galeorhinus galeus, in the northern Patagonian gulfs of Argentina. J Northwest Atl Fish Sci 2004, 37(December 2004):261-265.

8. Galeorhinus galeus. [http://www.iucnredlist.org/details/39352/0]

9. Guerrero RA, Lasta CA: Oceanografía física del estuario del Río de la Plata y el sistema costero de El Rincón. In Resultados de una Campaña de Evaluación de Recursos Demersales Costeros de la Provincia de Buenos Aires, Volume 21. Buenos Aires, Argentina: INIDEP Informe Técnico; 1998:29-54.

10. Macchi G, Acha M: Aspectos reproductivos de las principales especies de peces en la Zona Común de Pesca Argentino-Uruguaya y en El Rincón. November 1994. In Resultados de una Campaña de Evaluación de Recursos Demersales Costeros de la Provincia de Buenos Aires, Volume 21. Buenos Aires, Argentina: INIDEP Informe Técnico; 1998:67-89.

11. Lucifora LO: Ecología y Conservación de los Grandes Tiburones Costeros de Bahía Anegada. Provincia de Buenos Aires, Argentina: Universidad Nacional de Mar del Plata; 2003:410.

12. Wildlife Computers: Innovative Tags for Innovative Research. [www.wildlifecomputers.com]

13. Carey FG, Scharold JV: Movements of blue sharks (Prionace glauca) in depth and course. Mar Biol 1990, 106:329-342.

14. Nakamura I, Watanabe Y, Papastamatiou Y, Sato K, Meyer C: Yo-yo vertical movements suggest a foraging strategy for tiger sharks Galeocerdo cuvier. Mar Ecol Prog Ser 2011, 424:237-246.

15. West GJ, Stevens JD: The Use of Archival Tags for Studying the Movement and Swimming Behaviour of School Sharks. Deakin, Australian Capital Territory: Fisheries Research \& Development Corporation (Australia); 2001.

16. Peres M, Vooren C: Sexual development, reproductive cycle, and fecundity of the school shark Galeorhinus galeus off southern Brazil. Fish Bull 1991, 89:655-667.

17. Ferreira BP, Vooren CM: Age, growth, and structure of vertebra in the school shark Galeorhinus galeus (Linnaeus, 1758) from Southern Brazil. Fish Bull 1991, 89:19-31.

18. de Buen F: Contribuciones a la ictiología II: El tiburón vitamínico de la costa Uruguaya, Galeorhinus Vitaminicus nov. sp., y Algunas Consideraciones Generales Sobre Su Biología. Publicaciones Cientificas, Servicio Oceanografico y de Pesca, Ministerio de Industrias y Trabajo, Montevideo 1950, 4:153-162.

doi:10.1186/2050-3385-2-11

Cite this article as: Cuevas et al: Diving behaviour of the critically endangered tope shark Galeorhinus galeus in the Natural Reserve of Bahia San Blas, northern Patagonia. Animal Biotelemetry 2014 2:11.

\section{Submit your next manuscript to BioMed Central and take full advantage of:}

- Convenient online submission

- Thorough peer review

- No space constraints or color figure charges

- Immediate publication on acceptance

- Inclusion in PubMed, CAS, Scopus and Google Scholar

- Research which is freely available for redistribution 